\title{
ANALISIS EKONOMI USAHA PENANGKAPAN CUMI DI LAUT ARU
}

\section{ECONOMIC ANALYSIS OF SQUID FISHING BUSINNES IN ARU SEA}

\author{
Itok Agus Mulyanto $^{1)}$, Urip Rahmani ${ }^{\left.{ }^{*}\right)}$, Riena F. Telussa ${ }^{1)}$ \\ ${ }^{1}$ Fakultas Perikanan dan Ilmu Kelautan, Universitas Satya Negara Indonesia \\ * Korespondensi : urip_rabmani@yahoo.com
}

\begin{abstract}
ABSTRAK
Penelitian ini dilaksanakan pada bulan April - Juni 202 di Perum Perikanan Indonesia. Tujuan penelitian ini adalah untuk menganalisis penangkapan cumi di laut Aru menggunakan kapal pancing cumi, mengidentifikasikan kelayakan kapal KM Gemilang Samudra dan menyusun strategi pelaksanaan pengoperasian kapal penangkap.. Hasil penelitian menunjukkan kapal dalam keadaan layak operasi dengan rentang waktu dari tanggal 25 Juli 2019 sampai dengan 30 Desember 2021. Nilai R-C Ratio sebesar 0,61 yang artinya angka ini menunjukan penangkapan cumi KM Gemilang Samudra di Laut Aru tidak dapat dilanjutkan karena nilai R/C kurang dari 1. Strategi optimalisasi operasi kapal untuk mengupayakan nilai $\mathrm{R} / \mathrm{C}$ di atas angka 1 (satu) yakni dengan menaikkan nilai penerimaan dan mengurangi biaya operasional. Memaksimalkan hari operasi, menempatkan ABK yang berpengalaman, meng-update peralatan kapal, kontrol dan monitor area penangkapan sesuai hasil telaah perencanaan. Selain itu diperlukan upaya menekan biaya operasional serta menggerakkan kapal pada cuaca dan musim yang tepat.
\end{abstract}

KATA KUNCI: analisis ekonomi, kelayakan kapal, Laut Aru, pancing cumi

\begin{abstract}
This research was conducted in April - June 202 at Perum Perikanan Indonesia. The purpose of this study was to analyze the catching of squid in the Aru Sea using vessels with squid fishing gear, identify the feasibility of KM Gemilang Samudra and develop a strategy for implementing the operation of fishing vessels using squid fishing rods in the Aru Sea. The results of the study show that the ship is in a suitable condition for operation with a time span from July 25, 2019 to December 30, 2021. The RC Ratio value for catching KM Gemilang Samudra squid is 0.61, which means this figure shows that catching KM Gemilang Samudra squid in the Aru Sea cannot be continued because the $\mathrm{R} / \mathrm{C}$ value is less than 1 . The strategy for optimizing ship operations is to seek an $\mathrm{R} / \mathrm{C}$ value above the number 1 (one), namely by increasing the value of revenue and reducing operational costs. Maximizing operating days, placing experienced crew, updating ship equipment, controlling and monitoring fishing areas according to the results of planning studies. Beside it, reducing operational costs, and moving ships in the right weather and season.
\end{abstract}

KEYWORDS : economic analysis, Aru Sea, operations, squid jigging 


\section{PENDAHULUAN}

Cumi-cumi merupakan salah satu komoditas primadona di sektor perikanan yang diharapkan dapat meningkatkan devisa negara. Permintaan pasar ekspor yang cenderung meningkat serta sumberdaya yang cukup tersedia di Indonesia memberikan peluang sangat besar untuk dikembangkan. Tingginya permintaan pasar terhadap cumi-cumi sebagai komoditas ekspor Indonesia menjadikan cumi-cumi sebagai salah satu hasil tangkapan utama selain ikan, dan lobster, namun di sisi lain, pengetahuan masyarakat mengenai kelompok cumi-cumi masih sangat terbatas. Oleh sebab itu masyarakat perlu mengenal terkait penangkapan cumi-cumi di Indonesia dan upaya peningkatan jumlah tangkapannya.

Produksi cumi-cumi di Indonesia diperkirakan mencapai 58.250 ton per tahun (KKP, 2013). Potensi produksi cumicumi di WPPNRI 718 Laut Arafura diperkirakan mencapai 9.212 ton (KKP, 2017). Jumlah produksi ini ternyata masih jauh lebih kecil dari kebutuhan pasar dunia. Sebagai contoh, negara Amerika pada tahun 2010 membutuhkan 640.000 ton, Jepang 580.000 ton, sedangkan produksi dalam negeri hanya mampu menghasilkan 58.250 ton (KKP, 2013).

Perusahaan Umum Perikanan Indonesia (Perum Perindo) milik pemerintah di bawah kementerian BUMN melihat peluang ekspor cumi-cumi dan mempersiapkan armada penangkapan khusus berupa KM Gemilang Samudra untuk menangkap cumi-cumi dengan alat tangkap khusus berupa pancing cumi-cumi (squid jugging). Alat tangkap squid jigging mempunyai sifat yang sangat selektif, sehingga tidak ada tangkapan sampingan dari spesies yang dilindungi. Selain itu, karena alat tangkap ini tidak bersentuhan dengan dasar laut, maka tidak ada risiko kerusakan di dasar laut atau kerusakan alat tangkap.

Penelitian ini bertujuan untuk mengetahui keberhasilan yang telah dicapai dari penangkapan cumi-cumi dengan squid jigging yang menggunakan KM Gemilang Samudra yaitu dengan melakukan analisis usaha dan mengkajinya berdasarkan kriteria investasi. Langkah awal adalah dengan membuat strategi kelayakan usaha penangkapan cumi dengan kapal yang menggunakan alat tangkap pancing cumicumi (squid jigging).

Penelitian ini penting dilakukan untuk mengetahui apakah kapal penangkap cumi KM Gemilang Samudera layak untuk jalankan sehingga informasi dari penelitian ini menjadi referensi penyusunan kelayakan usaha penangkapan cumi-cumi di Laut Aru selain itu diharapkan dapat memberikan kontribusi positif khususnya sebagai acuan dari pelaku perikanan tangkap di Indonesia.

\section{METODE PENELITIAN}

\section{Jenis Data yang Digunakan}

Metode yang digunakan dalam penelitian ini yaitu metode studi kasus. Penelitian terhadap kasus ini difokuskan pada strategi manajemen risiko dengan menggunakan kapal perikanan di Perusahaan Umum Perikanan Indonesia (Perum Perindo). Data yang diambil meliputi data pengetahuan pemilik kapal terhadap data identitas kapal perikanan seperti Grosse akte yang merupakan bukti kepemilikan kapal, surat ukur, dan pass besar kapal perikanan, data biaya pembelian kapal perikanan, dan sistem pengoperasian kapal penangkap cumi. Data tersebut diperoleh melalui wawancara dan studi pustaka. Penentuan responden menggunakan teknik Purposive Sampling, yaitu dengan mempertimbangkan bahwa narasumber dianggap paling tahu tentang informasi yang dibutuhkan oleh peneliti sehingga akan memudahkan peneliti menjelajahi objek atau situasi yang diteliti (Sugiyono, 2010). Narasumber dalam penelitian ini sebanyak dua orang yakni Kepala Divisi Managemen Risiko dan Aset dengan Staf Ahli Direksi Bidang Penangkapan dan Pengelolaan Perikanan di Perusahaan Umum Perikanan Indonesia. 
Tabel 1. Matriks analisis SWOT

\begin{tabular}{|c|c|c|}
\hline Strength (S) dan & Strength (S) & Weakness (W) \\
\hline $\begin{array}{l}\text { Opportunity }(\mathrm{O}) \\
\text { dan Threat }(\mathrm{T})\end{array}$ & $\begin{array}{l}\text { Mengidentifikasi daftar kekuatan yang } \\
\text { dimiliki }\end{array}$ & $\begin{array}{l}\text { Mengidentifikasi daftar kelemahan } \\
\text { yang dimiliki }\end{array}$ \\
\hline Mengidentifikasi daftar peluang & Strategi SO & Strategi WO \\
\hline yang dapat diidentifikasi & $\begin{array}{l}\text { Menggunakan kekuatan yang } \\
\text { dimiliki untuk memanfaatkan } \\
\text { peluang yang teridentifikasi }\end{array}$ & $\begin{array}{l}\text { Mengatasi kelemahan dengan } \\
\text { memanfaatkan peluang yang } \\
\text { teridentifikasi }\end{array}$ \\
\hline Mengidentifikasi ancaman yang & Strategi ST & Strategi WT \\
\hline dapat diidentifikasi & $\begin{array}{l}\text { Menggunakan kekuatan yang } \\
\text { dimiliki untuk menghindar dari } \\
\text { ancaman yang teridentifikasi }\end{array}$ & $\begin{array}{l}\text { Menekan kelemahan dan } \\
\text { mencegah dari ancaman yang } \\
\text { teridentifikasi }\end{array}$ \\
\hline
\end{tabular}

Sumber : Rangkuti (2006)

\section{Analisa Data}

Analisis data dengan analisa SWOT digunakan untuk mengevaluasi kekuatan (strengths), kelemahan (weaknesses), peluang (opportunities), dan ancaman (threats) yang terlibat dalam suatu usaha dengan mengidentifikasi faktor internal dan eksternal yang mendukung ataupun tidak mendukung dalam mencapai tujuan (Rangkuti 2006) (Tabel 1). Penggunaan analisis SWOT ini dengan memaksimalkan kekuatan (strengths) dan peluang (opportunities) serta meminimalkan kelemahan (weaknesses) dan ancaman (threats) (Susanto et al, 2008).

Analisis deskriptif pada penelitian ini digunakan untuk mengidentifikasi permasalahan dan menjelaskan informasi mengenai kelayakan usaha penangkapan. Hasil olahan data dalam bentuk rangkuman hasil wawancara mengenai kelayakan kapal. Analisis ini bertujuan untuk membuat deskripsi, gambaran atau lukisan secara sistematis, faktual, dan akurat mengenai fakta-fakta yang ada di lokasi penelitian (Nazir, 2005). Beberapa perhitungan yang dilakukan, sbb:

\section{a) Pendapatan bersih}

Pendapatan bersih ( $\boldsymbol{\pi})$ dihitung berdasarkan selisih antara penerimaan total (total revue/TR) dengan biaya total (total cost/TC)(Yustiarini, 2008). Perhitungan ini bertujuan untuk mengetahui komponen- komponen input dan output yang terlibat di dalamnya dan besar keuntungan yang diperoleh dari usaha yang dilakukan:

$$
\boldsymbol{\pi}=\mathbf{T} \quad \mathbf{R}-\mathbf{T} \quad \mathbf{C}
$$

Keterangan:

$\boldsymbol{\pi}$ : Pendapatan bersih.

TR : Total Revenue atau total penerimaan.

TC : Total Cost atau total biaya.

Kriteria yang digunakan: $\boldsymbol{\pi}>0=$ untung,

$\pi<0=$ rugi

\section{b) $\quad$ R/C Ratio}

R/C Ratio adalah perbandingan antara penerimaan dengan biaya total (Suratiyah, 2015). Rumus untuk menghitung R/C Ratio, sebagai berikut:

$$
\frac{R}{C}=\frac{\text { Penerimaan total }(T R)}{\text { Biaya Total }(T C)}
$$

Keterangan:

TR : Besarnya penerimaan yang diperoleh.

TC : Besarnya biaya yang dikeluarkan. 


\section{HASIL DAN PEMBAHASAN}

KM Gemilang Samudra merupakan kapal penangkap cumi milik Perum Perikanan Indonesia yang dilengkapi alat tangkap pancing cumi (squid jigging) yang telah memenuhi semua persyaratan dan ketentuan kelayakan beroperasi sebagaimana aturan yang ditetapkan oleh Kementerian Kelautan dan Perikanan. Data spesifikasi dari kapal tersebut tersaji dalam Tabel 2.

\section{Produktivitas KM Gemilang} Samudra diharapkan dapat memberikan kontribusi berupa hasil tangkapan cumi yang menjadi tujuan utama penangkapannya. Kapal dengan bahan utama kayu ini sebenarnya sangat diharapkan menjadi contoh model alat produksi yang dapat dikembangkan di
Perum Perikanan Indonesia. Kapal yang dilengkapi dengan palka berpendingin refrigerasi ini mampu bertahan di fishing ground lebih dari 3 bulan. Kapal dirancang khusus untuk penangkap cumi dengan alat tangkap pancing cumi ini seperti tersaji dalam Gambar 1.

Salah satu ciri operasional kapal pemancing cumi adalah mengandalkan jumlah ABK, karena semakin banyak ABK semakin banyak hasil yang diharapkan. Namun demikian, tetap harus memperhatikan kapasitas dari tempat tidur. Adapun ABK yang mengoperasikan dipimpin oleh Nakhoda sekaligus merangkap fishing master (ahli penangkap ikan) atau sering disebut TEKONG dibantu oleh seorang Mualim yang berperan membantu melayarkan kapal dan administrasi di kapal.

Tabel 2. Spesifikasi KM Gemilang Samudra

\begin{tabular}{|c|c|c|}
\hline $\mathrm{NO}$ & URAIAN & KETERANGAN \\
\hline 1 & Nama Kapal & KM Gemilang Samudra \\
\hline 2 & ID Transmitter & 144739 \\
\hline 3 & No Register BKP & 010071 \\
\hline 4 & Tempat Pembangunan & Batang \\
\hline 5 & Tahun Pembangunan & 2014 \\
\hline 6 & Tonnase Kapal & GT 140 NT 42 \\
\hline \multirow[t]{2}{*}{7} & Dimensi Kapal & LoA $28,86 \mathrm{~m}$ \\
\hline & & B $\quad 7,90 \mathrm{~m}$ \\
\hline 8 & Bahan Kapal & Kayu \\
\hline \multirow[t]{4}{*}{9} & Mesin Utama Kapal & Merk Mitshubishi \\
\hline & & Tipe 8DCA \\
\hline & & No 0710691 \\
\hline & & Daya 365 PK \\
\hline \multirow[t]{3}{*}{10} & Palka Ikan & Jumlah \\
\hline & & $128,49 \mathrm{~m} 2$ \\
\hline & & Temperatur \\
\hline \multirow[t]{2}{*}{11} & Tanda Selar & SUNDA KELAPA/GT.140 \\
\hline & & No.8614/Bc \\
\hline 12 & Tanda Pengenal Kapal Perikanan & A/718/KP-LH/010071 \\
\hline 13 & Wilayah Pengelolaan Perikanan & 718 \\
\hline 14 & No SIPI & 26.19.0001.74.46841 \\
\hline 15 & Jenis Alat Penangap Ikan & Pancing Cumi (squid jigging) \\
\hline 16 & Pemilik & Perum Perikanan Indonesia \\
\hline 17 & Tanda Panggilan & YEC4272 \\
\hline
\end{tabular}

Sumber : Perindo, 2019 


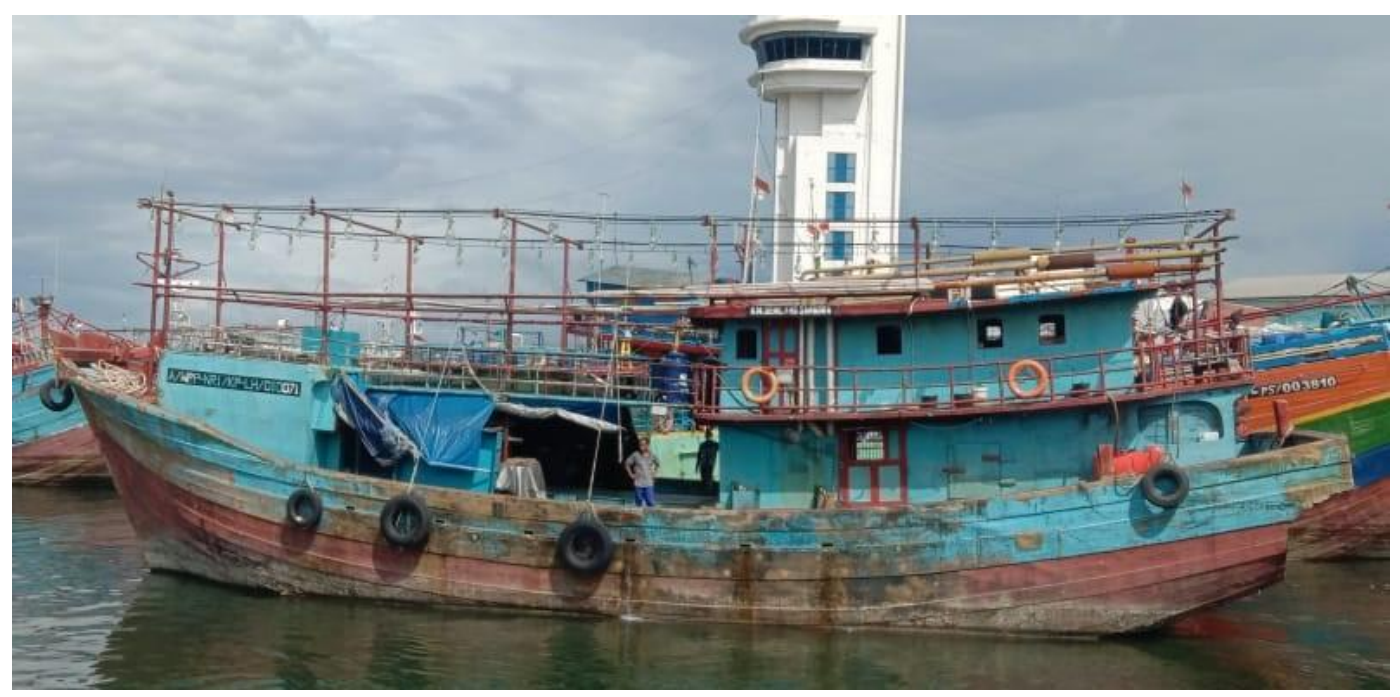

Gambar 1. KM Gemilang Samudra tampak samping kiri

Seorang ahli mesin kapal perikanan dengan jabatan Kepala Kamar Mesin (KKM) bertanggungjawab terhadap permesinan kapal yang dibantu oleh Masinis, serta kapal dilengkapi sejumlah kelasi yang bertugas memancing cumi pada malam hari. Nakhoda, Kepala Kamar Mesin (KKM), Masinis dan Mualim merupakan tenaga ahli perikanan yang berbasis kompetensi yang dibuktikan dengan kepemilikan ANKAPIN (Ahli Nautika Kapal Penangkap Ikan) dan ATKAPIN (Ahli Tekhnik Kapal Penangkap Ikan) serta didukung ABK dengan jabatan Kelasi yang bertugas sebagai pemancing.

Sesuai dengan Surat Ijin Penangkapan Ikan (SIPI), KM Gemilang
Samudra mendapatkan ijin untuk menangkap ikan di WPP 718 dari Kementerian Kelautan dan Perikanan. Cakupan perairan ini meliputi Laut Aru, Laut Arafuru dan Laut Timor bagian timur. Wilayah Pengelolaan Perikanan (WPP) ini menurut Peraturan Menteri Kelautan dan Perikanan No 18 tahun 2014 merupakan daerah penangkapan yang subur terutama untuk ikan-ikan dasar dan cumi. Laut Aru yang masuk di WPPNRI 718 merupakan daerah penangkapan yang kaya dengan cumi. Oleh karenanya KM Gemilang Samudra lebih banyak menangkap di daerah penangkapan tersebut. Adapun gambaran daerah penangkapan di Wilayah Pengelolaan Perikanan (WPP) 718 disajikan dalam Gambar 2.

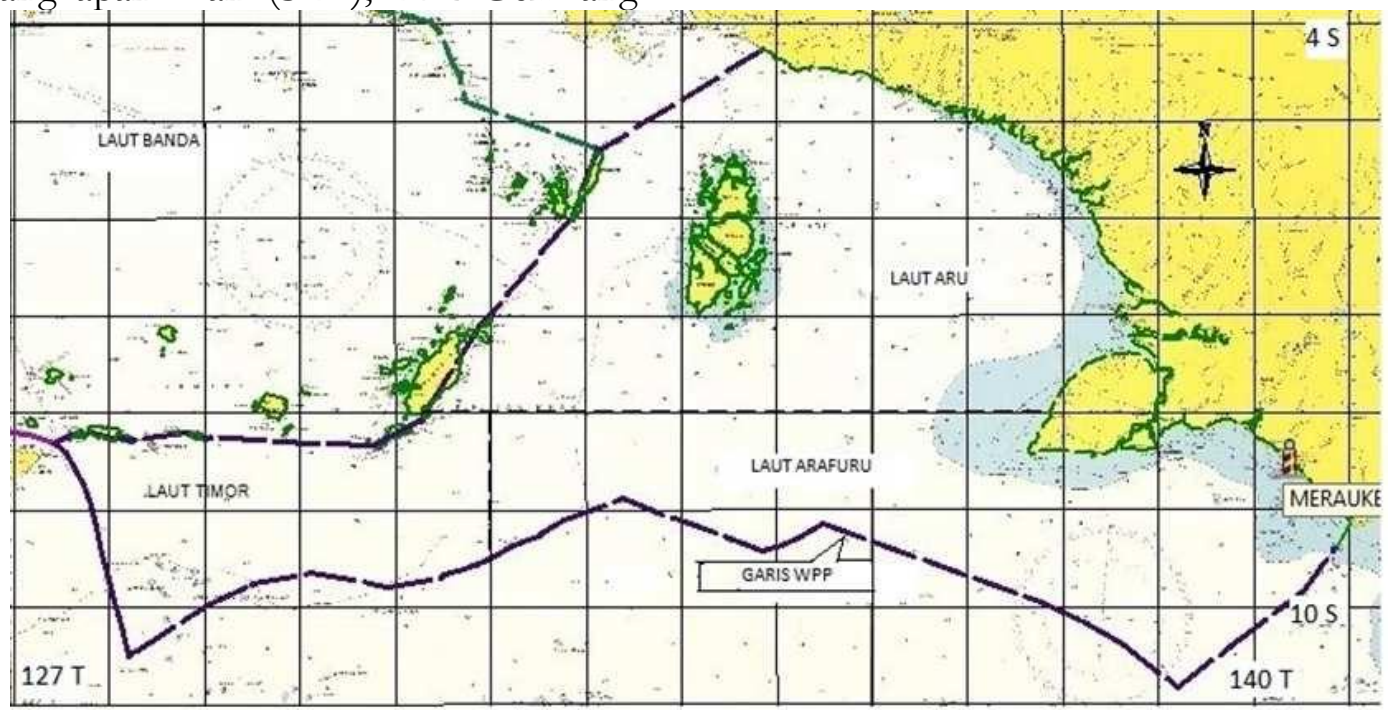

Gambar 2. Peta WPPNRI - 718 (Sumber KKP, 2014) 
Tabel 3. Jumlah hari menurut kegiatan

\begin{tabular}{lll}
\hline Uraian Kegiatan & Jumlah Hari & Prosentase (\%) \\
\hline Berlayar & 64 & 15,98 \\
Mancing & 204 & 41,80 \\
Fishing ground tidak mancing & 29 & 5,53 \\
Cuaca Buruk & 62 & 12,70 \\
Trouble & 85 & 17,42 \\
Pelabuhan & 32 & 6,56 \\
Total hari Trip & $\mathbf{4 7 6}$ & $\mathbf{1 0 0}$ \\
\hline
\end{tabular}

Sesuai batasan masalah dari analisis ekonomi usaha penangkapan cumi di Laut Aru adalah pengoperasian kapal penangkap cumi KM Gemilang Samudra milik Perusahaan Umum Perikanan Indonesia di Laut Aru mulai dari kapal berada di Pelabuhan Pangkalan, beroperasi di fishing ground dengan segala permasalahannya, singgah atau masuk di pelabuhan singgah dengan berbagai kegiatan sampai kapal kembali lagi di Pelabuhan Pangkalan dengan rentang waktu dari tanggal 25 Juli 2019 sampai dengan 15 Desember 2020. Tabel 3 berikut ini adalah jumlah ahri menurut kegiatan

Analisis Usaha

Analisis usaha dilakukan dengan menghitung biaya-biaya yang dikeluarkan dan penerimaan yang diperoleh oleh dalam pengoperasian KM Gemilang Samudra. Melalui perhitungan ini dapat memberikan gambaran dari suatu usaha yang dilakukan dan melihat keuntungan/kerugian yang diperoleh Perum Perikanan Indonesia dalam menjalankan penangkapan cumi menggunakan KM Gemilang Samudra di Laut Aru.

Penerimaaan Usaha

Berdasarkan perhitungan penerimaan pengoperasian KM Gemilang Samudra dalam periode penangkapan tanggal 12 Juni 2019 sampai tanggal 19 Desember 2020 mendapatkan hasil sebesar Rp. 2.380.934.680,50. Adapun rinciannya disajikan pada Tabel 4.

Investasi

Investasi untuk pengadaan 1 (satu) unit kapal penangkap cumi KM Gemilang Samudra adalah Rp 9.318.705.332,- yang merupakan harga beli kapal beserta perlengkapannya seperti tersaji pada Tabel 5 .

Tabel 4. Hasil tangkapan dan penerimaan KM Gemilang Samudra

\begin{tabular}{clc}
\hline Periode & Hasil Tangkapan (Kg) & Penerimaan (Rp) \\
\hline 12 Juni 2019 s/d 19 November 2020 & 22.231 & $2.380 .934 .680,50$
\end{tabular}

Sumber: Perindo, 2021

Tabel 5. Komponen Investasi KM Gemilang Samudra

\begin{tabular}{cllll}
\hline Uraian & Harga (Rp) & $\begin{array}{l}\text { Umur } \\
\text { Teknis }\end{array}$ & $\begin{array}{l}\text { Penyusutan } \\
/ \text { bulan }\end{array}$ & $\begin{array}{l}\text { Penyusutan } \\
/ \text { tahun }\end{array}$ \\
\hline Harga Perolehan Kapal & 9.318 .705 .332 & 16 th & 48.534 .924 & 582.419 .083 \\
\hline
\end{tabular}

Sumber: Perindo, 2021 
Tabel 6. Biaya variabel periode 12 Juni 2019 s/d 30 Desember 2020

\begin{tabular}{clrr}
\hline No. & \multicolumn{1}{c}{ Uraian } & \multicolumn{1}{c}{ Jumlah } & Persentase (\%) \\
\hline 1 & Biaya Perizinan & 98.408 .600 & 3,12 \\
2 & Biaya Perbekalan Kapal & 549.824 .980 & 17,44 \\
3 & Biaya Pelatihan & 56.000 .000 & 1,78 \\
4 & Biaya Gaji, Upah, Bonus & 754.251 .000 & 23,92 \\
5 & Biaya Pemeliharaan Kapal & 198.285 .000 & 6,29 \\
6 & Biaya Perlengkapan Kapal & 178.082 .100 & 5,65 \\
7 & Biaya Transportasi & 6.500 .000 & 0,21 \\
8 & Biaya Bahan Bakar Kapal & 1.258 .164 .300 & 39,90 \\
9 & Biaya pengiriman / kontainer & 53.878 .920 & 1,71 \\
\hline & Jumlah & 3.153 .394 .900 & 100 \\
\hline
\end{tabular}

Sumber: Perindo, 2021

Biaya

Biaya adalah biaya selama operasi penangkapan cumi mulai kapal berangkat sampai kembali lagi ke pelabuhan pangkalan di Pelabuhan Perikanan Samudera Nizam Zachman Jakarta dilakukan. Total biaya yang dikeluarkan dalam operasi penangkapan cumi terdiri atas biaya tetap dan biaya variabel. Biaya tetap sebesar Rp. 180.000.000.- (seratus delapan puluh juta rupiah) adalah biaya pungutan hasil perikanan berupa penerimaan negara bukan pajak (PNBP) yang menjadi kewajiban pelaku usaha sebagai konpensasi dalam mendapatkan izin penangkapan ikan ditambah dengan penyusutan sebesar Rp 582.419.083,- (lima ratus delapan puluh dua juta empat ratus sembilan belas ribu delapan puluh tiga rupiah) sehingga biaya tetap sebesar $\mathrm{Rp}$ 762.419.083,- ( tujuh ratus enam puluh dua juta empat ratus sembilan belas ribu delapan puluh tiga) pertahunnya. Sedangkan untuk biaya variabel yang dikeluarkan sebesar Rp 3.153.394.900,merupakan biaya pembelian bahan bakar solar, makanan, biaya perizinan selama operasional serta biaya lainnya sebagaimana terlampir dalam Tabel 6.

\section{Keuntungan Kerugian}

Keuntungan dari suatu usaha adalah nilai penerimaan dikurangi dengan nilai biaya. Perhitungan usaha dari operasional penangkapan cumi KM Gemilang Samudra yang meliputi penerimaan dan biaya sebagaimana tersaji dalam Tabel 7.

Berdasarkan data Tabel 8 menunjukkan bahwa usaha penangkapan cumi dengan KM Gemilang Samudra pada periode 12 Juni 2019 s/d 30 Desember 2020 mengalami kerugian. Analisis penyebab kerugian diantaranya rendahnya hari penangkapan yang disebabkan tidak tepatnya menentukan titik penangkapan, cuaca buruk, kerusakan mesin, gangguan kesehatan ABK yang ada di atas kapal dan penyebab lainnya sehingga membuat rendahnya hari produktivitas.

Pemakaian bahan bakar merupakan faktor analisis penyebab tingginya nilai biaya operasi, mengingat kebutuhan bahan bakar untuk operasional kapal - kapal perikanan yang besarnya hampir $40 \%$ dari total biaya variabel harganya mahal serta terbatasnya kapal yang mendapatkan subsidi harga bahan bakar dari pemerintah.

Analisis Imbangan Penerimaan dan Biaya (R-C Ratio)

Nilai R-C Ratio pada penangkapan cumi KM Gemilang Samudra adalah sebesar 0,61 yang artinya angka ini menunjukan penangkapan cumi KM Gemilang Samudra di Laut Aru tidak dikembangkan karena nilai $\mathrm{R} / \mathrm{C}$ kurang dari 1 (satu). 
Tabel 7. Laporan rugi laba periode 12 Juni 2019 s/d 30 Desember 2020

\begin{tabular}{llr}
\hline & \multicolumn{1}{c}{ Uraian } & \multicolumn{1}{c}{ Total (Rp) } \\
\hline I. Penerimaan & \multicolumn{1}{c}{ Pendapatan Cumi } & $2.380 .934 .680,50$ \\
& Jumlah & $2.380 .934 .680,50$ \\
II. Biaya Variabel & & \\
& 1. Biaya Perizinan & $98.408 .600,00$ \\
& 2. Biaya Perbekalan Kapal & $549.824 .980,00$ \\
& 3. Biaya Pelatihan & $56.000 .000,00$ \\
& 4. Biaya Gaji, Upah, Bonus & $754.251 .000,00$ \\
& 5. Biaya Pemeliharaan Kapal & $198.285 .000,00$ \\
& 6. Biaya Perlengkapan Kapal & $178.082 .100,00$ \\
& 7. Biaya Transportasi & $6.500 .000,00$ \\
8. Biaya Bahan Bakar Kapal & $1.258 .164 .300,00$ \\
9. Biaya pengiriman / kontainer & $53.878 .920,00$ \\
Jumlah & $3.153 .394 .900,00$ \\
& & \\
\hline TII. Biaya Tetap & Perizinan & $180.000 .000,00$ \\
& Penyusutan & $582.419 .083,00$ \\
& Jumlah & $762.419 .083,00$ \\
\hline Laba/Rugi & & \\
\hline
\end{tabular}

Sumber: Perindo, 2021

Rute atau alur perjalan operasi KM dari pelabuhan pangkalan ke fishing ground, penangkapan di fishing ground, bongkar hasil tangkapan di pelabuhan singgah, kembali lagi ke fishing ground sampai kembali lagi ke pelabuhan pangkalan sebagai satu strategi operasi tersaji pada Gambar 3.

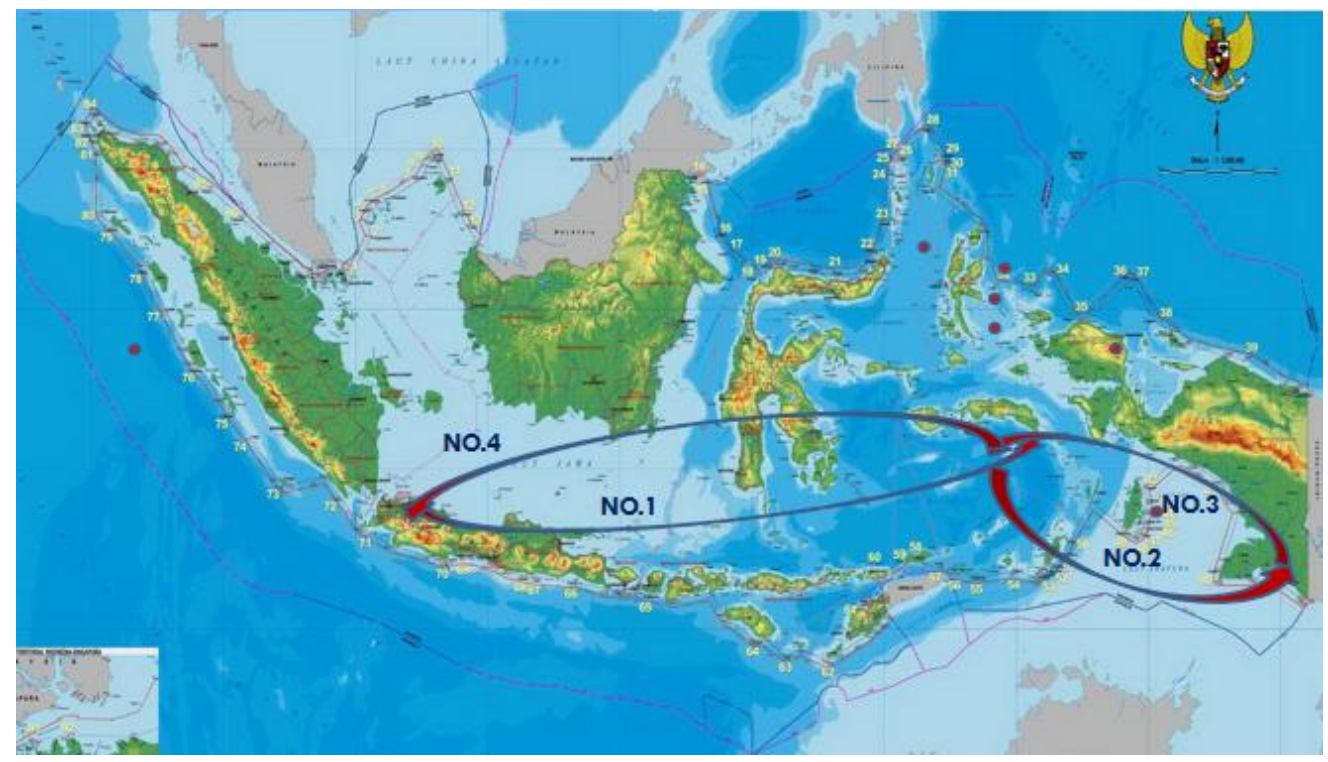

Gambar 3. Tracking perjalanan operasional KM Gemilang Samudra 


\section{Analisis SWOT}

Hasil analisis SWOT diperlihatkan pada tabel berikut ini.

Tabel 8. Strategi operasional

\begin{tabular}{|c|c|c|}
\hline $\operatorname{lan}$ & Strength (S) & Weakness (W) \\
\hline $\begin{array}{l}\text { Opportunity }(\mathrm{O}) \text { dan } \\
\text { Threat }(\mathrm{T})\end{array}$ & $\begin{array}{l}\text { 1. } \text { Perusahaan telah } \\
\text { memiliki kapal } \\
\text { penangkap cumi140 GT } \\
\text { 2. Tersedianya sumberdaya } \\
\text { ABK kapal } \\
\text { 3. Hasil tujuan tangkapan } \\
\text { merupakan produk } \\
\text { unggulan dengan harga } \\
\text { tinggi dan stabil } \\
\text { 4. Operasional } \\
\text { penangkapan yang masih } \\
\text { diijinkan }\end{array}$ & $\begin{array}{l}\text { 1. Musim cumi yang tidak } \\
\text { sepanjang tahun ada merupakan } \\
\text { faktor alam } \\
\text { 2. Tingkat kecakapan/keahlian } \\
\text { ABK yang beragam } \\
\text { 3. Kondisi kapal yang sewaktu- } \\
\text { waktu ada kendala tekhnis } \\
\text { 4. Kualitas hasil tangkapan yang } \\
\text { beragam } \\
\text { 5. Perlunya maintenance kapal } \\
\text { 6. Pengawasan yang tidak optimal }\end{array}$ \\
\hline Opportunity (O) & Strategi SO & Strategi WO \\
\hline $\begin{array}{l}\text { 1. Fishing ground /daerah } \\
\text { penangkapan yang sangat } \\
\text { luas } \\
\text { 2. Pasar produk yang sangat } \\
\text { terbuka } \\
\text { 3. Produk yang banyak diminati } \\
\text { 4. Alat tangkap yang ramah } \\
\text { lingkungan } \\
\text { 5. Peluang usaha yang masih } \\
\text { terbuka }\end{array}$ & $\begin{array}{l}\text { 1. Melakukan strategi } \\
\text { optimalisasi kapal } \\
\text { penangkap } \\
\text { 2. Harus lebih efektif operasi } \\
\text { di fishing ground di wpp } 718 \\
\text { 3. Hasil tangkapan KM } \\
\text { Gemilang Samudra } \\
\text { merupakan produk } \\
\text { dengan pasar ekspor } \\
\text { 4. Memanfaatkan ijin } \\
\text { operasional semaksimal } \\
\text { dan secara efektif }\end{array}$ & $\begin{array}{l}\text { 1. Kontrol dan monitor area } \\
\text { pancing sesuai hasil telaah di } \\
\text { perencanaan. } \\
\text { 2. Menggerakkan kapal ke point } \\
\text { fishing ground yang aman dan } \\
\text { berpeluang mendapatkan hasil } \\
\text { 3. Perlu menyiapkan Nakhoda dan } \\
\text { ABK yang berpengalaman dan } \\
\text { kompeten } \\
\text { 4. Menggerakkan kapal ke titik } \\
\text { point fishing ground yang } \\
\text { terjangkau dari pelabuhan } \\
\text { singgah sewaktu-waktu ada } \\
\text { trouble } \\
\text { 5. Penerapan system/standar } \\
\text { operasional (SOP) dalam setiap } \\
\text { kegiatan }\end{array}$ \\
\hline Threat (T) & Strate & Strateg \\
\hline $\begin{array}{l}\text { 1. Gelombang tinggi di fishing } \\
\text { ground } \\
\text { 2. Keselamatan kapal dan ABK } \\
\text { 3. Produk rusak karena } \\
\text { kerusakan mesin } \\
\text { 4. Musim yang tidak menentu } \\
\text { 5. Mutu produksi yang rendah } \\
\text { Alat tangkap masih manual } \\
\text { sehingga produktivitasnya } \\
\text { tidak maksimal } \\
\text { 6. Perubahan kebijakan dari } \\
\text { pemerintah yang sewaktu- } \\
\text { waktu berubah }\end{array}$ & $\begin{array}{l}\text { 1. Menempatkan Nakhoda } \\
\text { dan ABK yang handal dan } \\
\text { berpengalaman tentang } \\
\text { teknik penangkapan } \\
\text { pancing cumi } \\
\text { 2. Melakukan update dan } \\
\text { pembaharuan peralatan } \\
\text { dan mesin kapal } \\
\text { 3. Melakukan pelatihan } \\
\text { keterampilan kepada } \\
\text { Nakhoda dan ABK } \\
\text { 4. Update kebijakan } \\
\text { pemerintah }\end{array}$ & $\begin{array}{l}\text { 1. Melakukan pengawasan dan } \\
\text { reviu secara berkala untuk } \\
\text { perbaikan sistem operasional } \\
\text { 2. Memaksimalkan hari operasi } \\
\text { 3. Mengurangi hari/ waktu stby di } \\
\text { pelabuhan } \\
\text { 4. Menjalin hubungan baik } \\
\text { kepadainstansi terkait juga } \\
\text { kepada kapal penangkap lainnya } \\
\text { yang beroperasi bersama }\end{array}$ \\
\hline
\end{tabular}

\section{KESIMPULAN}

1) Berdasarkan analisis perhitungan imbangan penerimaan dan biaya ( $\mathrm{R}-\mathrm{C}$ Ratio) adalah sebesar 0,61 yang artinya angka ini menunjukan penangkapan cumi KM Gemilang Samudra di Laut Aru tidak dapat dikembangkan karena nilai R/C kurang dari 1 (satu)

2) Rendahnya hari penangkapan/hari memancing yang diakibatkan faktor cuaca, kerusakan kapal, jumlah dan 
kurang kompetennya ABK menyebabkan turunnya/rendahnya hasil tangkapan, sehingga perlu pembenahan strategi operasional . Saran

1) Mengupayakan nilai $\mathrm{R} / \mathrm{C}$ diatas angka 1 (satu) yakni dengan menaikkan nilai penerimaan dan mengurangi biaya operasional

2) Dengan kapal yang sudah layak operasi perlu menata ulang strategi pengoperasiannya.

3) Melaksanakan strategi optimalisasi operasi kapal dengan memaksimalkan hari operasi, menempatkan ABK yang berpengalaman, mengupdate peralatan kapal, kontrol dan monitor area penangkapan sesuai hasil telaah perencanaan, menekan biaya operasional, serta menggerakkan kapal pada cuaca dan musim yang tepat

\section{DAFTAR PUSTAKA}

Badriyah, S.M, Mahmudah.S., Soemarmi, A. 2019. Leasing sebagai Alternatif Pembiayaan Kapal bagi Nelayan Kecil di Kota Pekalongan. Masalah-masalah Hukum. 48 (2): 204-214

Bayu, P. 2014. Analisis Produksi Cumicumi Unit Penangkapan Bouke Ami di PPS Nizam Zachman, Jakarta. (Skripsi) Departemen Pemanfaatan Sumberdaya Perikanan Fakultas Perikanan dan Ilmu Kelautan. Institut Pertanian Bogor. Bogor.

Budiman, M.S., Iskandar, B.H, Suboer, D.A., 2016. Penataan Sertifikasi Kompetensi Awak Kapal Penangkap Ikan di Indonesia. Jurnal Teknologi Perikanan dan Kelautan. 7(2):146-152

Food and Agriculture Organization of the United Nations (FAO). 2017. Fishery and Aquaculture Insurance in China.
Fyson, J. 1985. Design of Small Fishing Vessels. Fishing News LTD. England (ENG): London.

Huda, M.A., Herry, B., Setyanto, I. 2012. Implementasi Regulasi Nasional terkait Keselamatan Kapal Penangkap Ikan di PPN Pekalongan, Journal of Fisheries Resources Utilization Management and Technology Volume 1, Nomor 1.

Kasmir dan Jakfar. 2012. Studi Kelayakan Bisnis. Kencana. Jakarta

Kementerian Kelautan dan Perikanan Republik Indonesia. 2014. Keputusan Menteri Kelautan dan Perikanan Republik Indonesia Nomor 54/KERMEN-KP/2014 tentang Rencana Pengelolaan Perikanan Wilayah Pengelolaan Perikanan Negara Republik Indonesia 718.

Kementerian Kelautan dan Perikanan Republik Indonesia. 2017. Keputusan Menteri Kelautan dan Perikanan Republik Indonesia Nomor 50/KERMEN-KP/2076 tentang Estimasi Potensi, Jumlah Tangkapan yang Diperbolehkan, dan Tingkat Pemanfaatan Sumber Daya Ikan di Wilayah Pengelolaan Perikanan Negara Republik Indonesia.

Kementerian Kelautan dan Perikanan Republik Indonesia. 2019. Keputusan Menteri Kelautan dan Perikanan Republik Indonesia Nomor 5/PERMEN-KP/2019 tentang Perubahan atas Peraturan Menteri Kelautan dan Perikanan Nomor 23/PERMEN-KP/2013 tentang Pendaftaran dan Penandaan Kapal Perikanan.

Kementerian Kelautan dan Perikanan Republik Indonesia. 2021. Keputusan Menteri Kelautan dan Perikanan Republik Indonesia Nomor 59/PERMEN-KP/2020 
tentang Jalur Penangkapan Ikan dan Alat Penangkapan Ikan di Wilayah Pengelolaan Perikanan Negara Republik Indonesia dan Laut Lepas.

Lindawati dan Rahadian, R. 2016. Identifikasi Faktor dan Penilaian Risiko pada Usaha Perikanan Tangkap di Kabupaten Sambas. Jurnal Sosial Ekonomi Perikanan Kelautan. 11(1): 99-107

Marzuki, P. 2008. Penelitian Hukum. Prenada Media Group. Jakarta.

Nazir, M. 2005. Metodologi Penelitian. Ghalia Indonesia. Bogor.

Parappurathu, S., Ramachandran, C., Gopalakrishnan, A. 2017. Marine Fisheries Information Service. Technical and Extension Series. India (IND) : Indian Council of Agricultural Research.

Permana. 2015. Pemanfaatan dan Pemasaran Sumberdaya Cumicumi (Loligo sp) yang Didaratkan di Pelabuhan Perikanan Nusantara (PPN) Kejawanan Kota Cirebon, Jawa Barat, Journal of Fisheries Resources Utilization Management and Technology. Volume 4: 97-106

Perusahaan Umum Perikanan Indonesia. 2021. Rencana Kerja Anggaran Perusahaan Tahun 2021. Jakarta.

Rangkuti, F. 2006. Teknik Mengukur dan Strategi Meningkatkan Kepuasan
Pelanggan. PT Gramedia Pustaka Utama. Jakarta

Simarmata, A. 2018. Analisa Usaha Penangkapan Cumi-cumi (Loligo sp) dengan Alat Tangkap Bouke Ami (Stick Held Dip Net) yang Didaratkan di Pelabuhan Perikanan Samudera (PPS) Belawan Propinsi Sumatera Utara.

Undang-Undang Republik Indonesia Nomor 45 Tahun 2009 tentang Perikanan

Undang-Undang Republik Indonesia Nomor 40 Tahun 2013 tentang Badan Usaha Milik Negara (BUMN)

Undang-Undang Republik Indonesia Nomor 17 Tahun 2008 tentang Pelayaran

Wulandari, D.A. 2018. Morfologi, Klasifikasi, dan Sebaran Cumi-cumi Famili Lolinginidae. Oceana, Volume XLIII. No 2 : 48-65

Yustriani, A. 2008. Kajian Pendapatan Nelayan dari Usaha Penangkapan Ikan dan Bagian Retribusi Pelelangan Ikan di Pangkalan Pendaratan Ikan di Muara Angke (Skripsi). Departemen Pemanfaatan Sumberdaya Perikanan Fakultas Perikanan dan Ilmu Kelautan. Institut Pertanian Bogor. Bogor 